\title{
NO. 111.
}

Description of a Species of Orang, from the north-eastern province of British East India, lately the kingdom of Assam. By Richard Harlan, M.D., \&.c. Read November 19th, 1830.

\section{Simia, Linn.-Hilobates, Illig.}

S. Hoolock. Colour of the skin and hair, deep black; canine teeth very long; a band of whitish grey hairs over each eye.

Dimensions. Total length, about two feet six inches. Humerus eight inches ninetenths ; radius nine inches; hand, from the beginning of the wrist to the end of the fingers, six inches; inferior extremities about thirteen inches; the foot six inches.

Habitat. Garrow-Hills, Assam, and probably extending into China between latitudes twenty-five and twenty-seven degrees north. Cab. of A. N. S. Philadelphia.

The present specimen is an adult male; and forms one of three individuals which lived some time in possession of Dr M. Burrough, who has lately returned from India, with a magnificent collection of rare and valuable skins of birds and quadrupeds, selected principally from the plains of the Burrampooter river. Dr Burrough informs me, that there is not much exterior difference between the adult male and female. The young, we shall have occasion to notice, possesses several characteristic marks. They were all taken on the Garrow-Hills, in the vicinity of Goalpara, in the latitude of twenty-six degrees north; they very soon became tamed, especially the young one; they were docile, affectionate, and rather inclined to melancholy.

According to the accounts of the natives, these animals are not found south of the regions specified. There can not be the least 


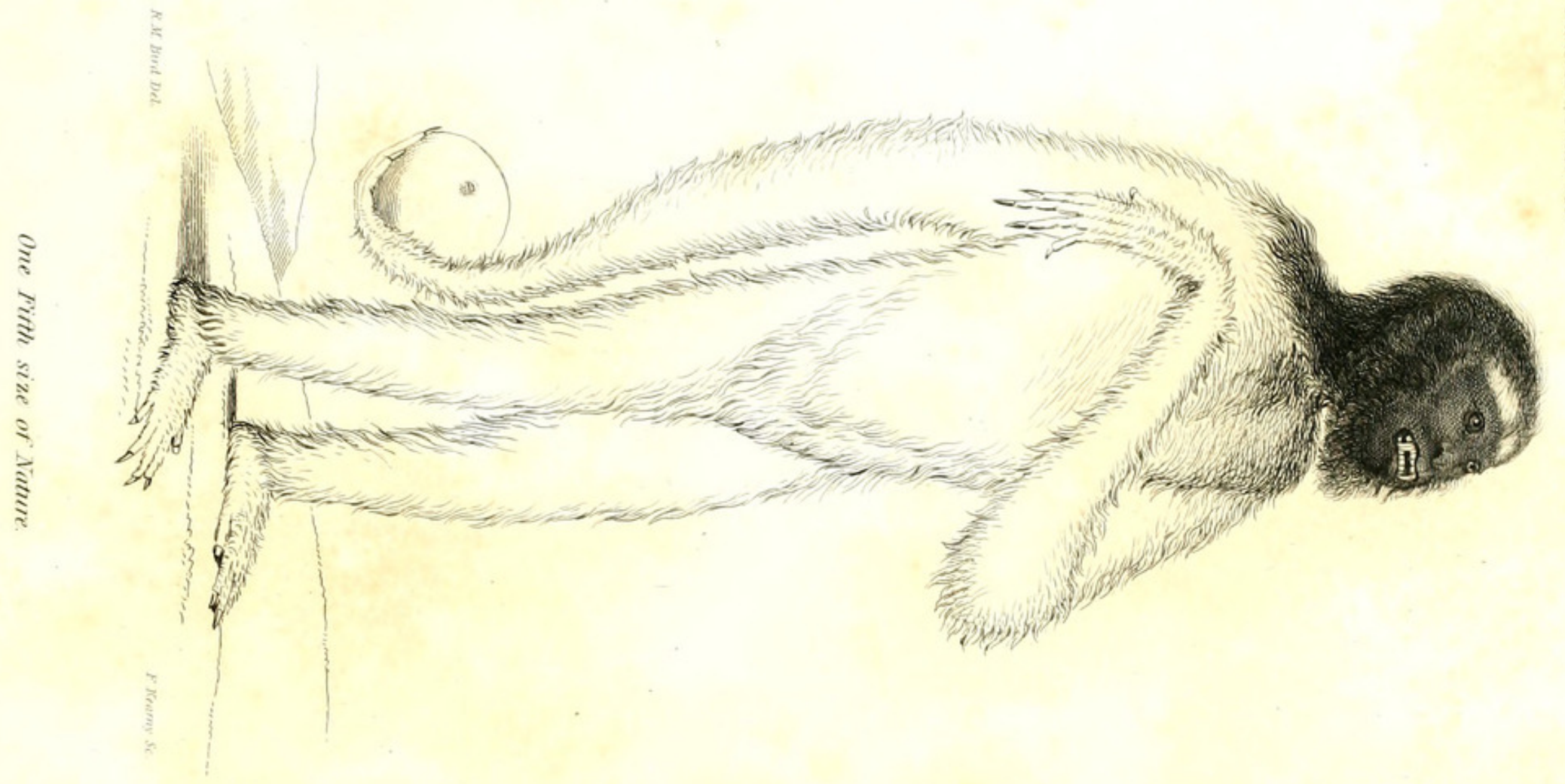

0
0
0
0
0
0
0
0
0
0
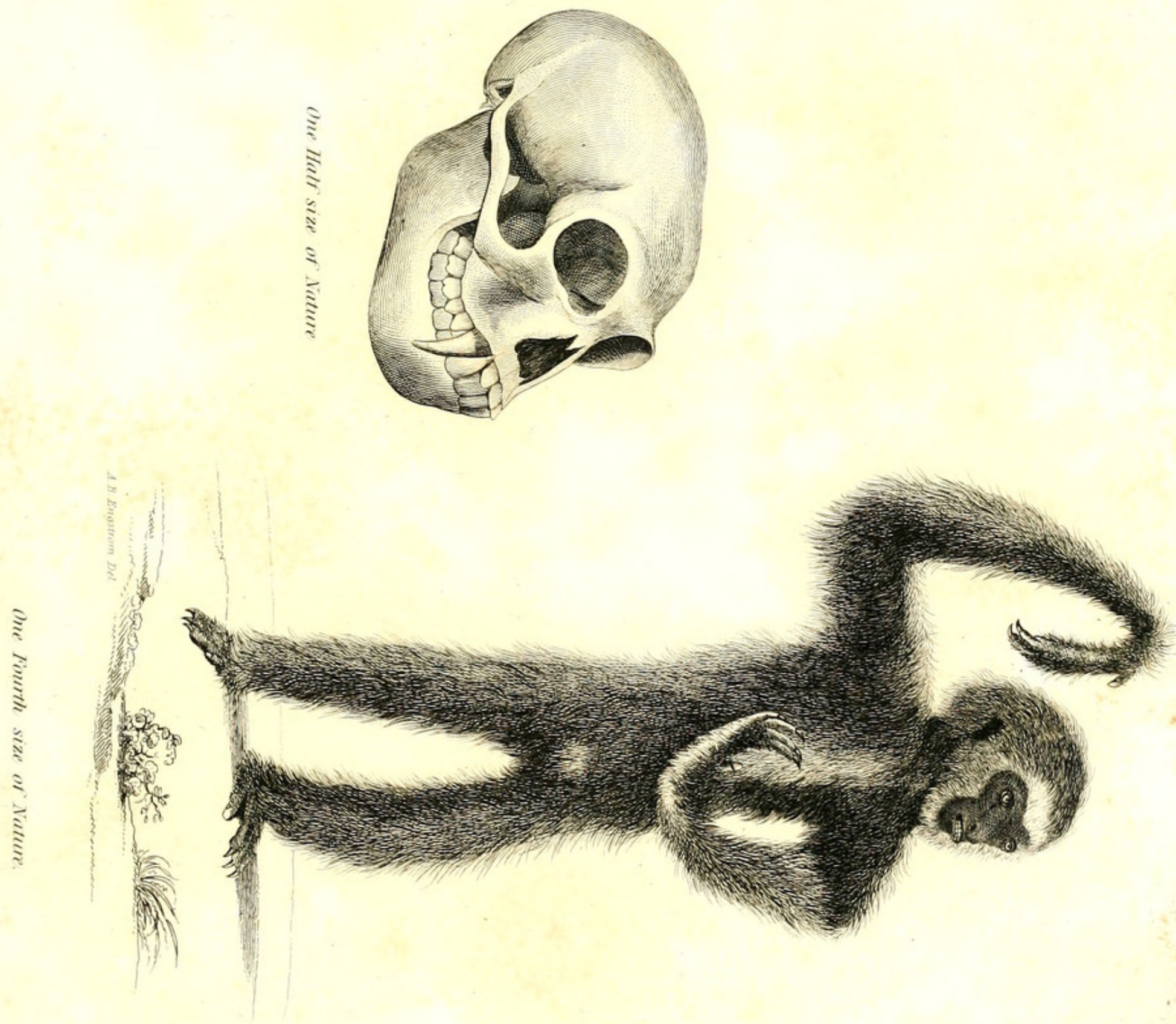
$\cdots$ 
doubt but that this species is the same mentioned cursorily in Latreille's Buffon Vol. XXXV. p. 140. The observations relative to the habits of this species contained in this account, corresponding in so many respects with the specimens introduced by Dr Burrough, induces us to make the following translation. "Mr Gordon has sent me the drawing of an Orang, which the King of Assam had made a present to $\mathrm{Mr}$ Harwood, president of the provincial council of Dinagipal. The brother of $\mathrm{Mr}$ Harwood brought it to the Cape of Good Hope and presented it to $\mathrm{Mr}$ Gordon, with whom it unfortunately lived only one day. It had been attacked with scurvy on ship-board, and on arriving at the Cape was so feeble as to die at the end of twenty-four hours; thus $\mathrm{Mr}$ Gordon had only time to make a drawing of it; and not being able to make any observations on its habits, has communicated the information he obtained from Mr Harwood, as follows. 'This Orang-outang, named Voulock [Hoolock] in its native country, was a female, and regularly menstruated, but the discharge was interrupted after the attack of scurvy. She was of a very gentle disposition, only monkeys displeased her, whose presence she could not endure. She always walked in the upright attitude, and could even run very fast: when walking on a table, or among china-ware, she was very careful not to break any thing; when climbing she used only her hands; her knees resembled those of man. Her cry was sharp and deafening, pronouncing often and frequently repeating the syllables yaa-hoo! yaa-hoo! yaa-hoo!-with the emphasis on the last syllable, particularly on the terminal sound: when she heard any noise resembling this, she commenced crying also. When contented, she emitted a low guttural sound. When sick she whined like a child, and was fond of being nursed. Her food consisted principally of vegetables and milk; she would never touch a dead animal, or eat meat, and refused even to eat from a plate which had contained meat" [in this respect she differed from those individuals in the possession of Dr Burrough, these latter would eat meat occasionally]. "When thirsty, she plunged her fingers into the water and licked them: she voluntarily covered herself with pieces of sail-cloth, but would not endure clothes. She would come when called by name. She was commonly melancholy and pensive. When answering to the VoL. IV.-O 
calls of nature on board of ship, she would hold on to a rope and evacuate into the sea.

The length of her body was two feet five inches and a half-the circumference of the chest was one foot two inches-that of the thinnest part of the body was ten inches and a half: when in health she was fatter, and had calves to the legs.

The drawing had been taken during illness, or after death, when the subject was greatly emaciated : there were nails on all the fingers."

Notwithstanding the high northern latitude of the country in which this species is native, it would appear that they are less able than even other Gibbons to endure the hardships of captivity and change of climate. All those belonging to Dr B. died, either on their passage down the river from Goalpara, or on board vessel before they arrived at the Cape of Good Hope.

The Gibbons, or long armed apes, in many particulars, all bear a very close resemblance to each other. Thus the S. lar., leucisca, agilis, syndactylus, and concolor, which includes all the species hitherto described, differ from each other only in some particulars of size, colour, proportions and markings. The present specimen is as strongly characterized, as distinct, as any of the others. In some of its habits, particularly in its mode of drinking, it resembles the Siamang of Sir Stamford Raffles, or S. syndactylus; but differs widely in other respects. In form, size, and proportion, it is most closely allied to the females of the S. agilis of F. Cuv., but is very different in colours and markings, especially the young individuals of the two species, which differ totally in these respects; the male and female resemble each other in the present species, but the sexes are different in size and colour in the S. agilis; the two species differ also in their habits; both differ also from the S. lar., Linn.

The skin of the present species is of a deep black colour, which, on the hands at least, is not confined to the rete mucosum, as the cutis vera of the palms remains black after maceration, so as to destroy the epidermis.

The hair, which is universally black, with the exception of the grey band across the forehead of the adult, covers the back of the hand to the ends of the fingers, and on the palm descends as low as half the 
length of the metacarpal bones. In both old and young the hair on the fore-arm is reversed.

In the young individual, which is about half the size of the adult, besides the difference of colour, a remarkable peculiarity was noticed in the relative proportions of the arm and fore-arm, as will be observed in the following measurements. Total length, two feet six or eight inches; humerus, eight inches nine-tenths; ulna, ten inches threetenths; femur, eight inches: tibia seven inches; length of the head from the vertex to the chin, four inches five-tenths-breadth, two inches five-tenths.

In the young animal the fore-arm is shorter than the arm, a fact at variance with the proportions of those parts, not only in the Orangs, but in all the race of adult Simiæ. In the adult of this species the arm and fore-arm are within one inch two-tenths of being equal in length.

In the S. concolor, (Harl. Journ. A. N. S. Vol. V. p. 229, pl. ix.) the fore-arm is two inches and a half longer than the arm*. If M. F. Cuvier's account of the dimensions of the S. agilis be correct, there is six inches difference between the length of the arm and fore-arm; but if the author has improperly included the hand and fingers in the term "fore-arm," the proportions of these parts are nearly similar in the S. agilis, and S. Hoolock.

The colour of the young of the present species is blackish-brownback of the hands and feet sprinkled with grey-buttocks greyish: a tuft of greyish hairs grows from the point of the chin, and a line of the same colour extends along the middle of the front of the body: the band of grey over the eyes of the adult is generally interrupted in the middle of the forehead by a line of black hairs-which is absent in the young one; the band is broader in the latter, in the proportion of seven-tenths to four-tenths.

Buffon, speaking of the habitat of the Gibbons (Vol. XXXV. p. 200 ), remarks, "it appears to inhabit the more northern countries, and that the ape of the province of Gannaure, on the frontiers of China,

* In the Bull des. Sc. Univers. 1830, M. Lesson remarks that the S. concolor is probably a variety of the S. lar., notwithstanding the former animal has two dorsal vertebræ, and two ribs more than the former, not to mention other distinctive characters. 
ought to be referred to the Gibbon; which some travellers have indicated under the name of Féfé."

The following extract is quoted by Buffon; "in the kingdom of Gannaure, frontier of China, there exists an animal very rare, which they call Fefe; it has almost the human form; the arms very long; the body black and hairy; walks lightly and very fast." (Recueil des Voyages, S.c. Rouen, 1716, Tome III. p. 168.)

It is this Féfé, which the traveller Nieuhoff describes as carnivorous and anthropophagous; a character attributable to the extreme length of the canine teeth. It is highly probable that Féfé is the Chinese name for the Assamese "Hoolock." The dentition of this species bears close analogy to that of the S. agilis or Wou-wou, so accurately detailed by F. Cuv. (Dent des Mammiferes, \&c.): the only difference is the greater length of the canines of the Hoolock, and the obsolete appearance of the longitudinal grooves, especially that on the posterior face of this tooth.

In all particulars not mentioned this species resembles the other Gibbons. A drawing of the adult male and young female, also the cranium of the adult male, accompanies the description.

For the details concerning the habits of the specimens which form the subjects of the present description, we refer to the observations contained in the annexed letter from Dr Burrough.

\section{"To Richarl Harlan, M.D.}

"The specimens of Ourang Outang; or Gibbons, furnished you, were obtained by me during my late excursion into the interior of Bengal. They were presented to me by Captain Alexander Davidson of the honourable East India Company, stationed at Goalpara, situate on the Burrampooter river in Assam. This district of country was formerly attached to the Burmese empire; but at present is in possession of the East India Company, and constitutes the north eastern limits of their territory in this quarter.

"The Ourang, of which I am now to speak, called by the Assamese 'Hoolock,' is to be met with on the Garrow-Hills in the vicinity of 
Goalpara, between latitudes twenty-five and twenty-eight degrees north, and the specimens brought to this country by me were taken within a few miles of the town of Goalpara. The full-grown one, which at this time you have prepared, was in my possession, alive, from the month of January to May, when it died from a blow it received across the lumbar region, inadvertently inflicted with a small stick by one of my servants at Calcutta. They inhabit more particularly the lower hills, not being able to endure the cold of those ranges of the Garrows of more than four or five hundred feet elevation. Their food in the wild state consists, for the most part, of fruits common only to the jungle in this district of country, and they are particularly fond of the seeds and fruits of that sacred tree of India, called the Peepul-tree, and which on the Garrow-Hills attains a very large size. They likewise take of some species of grass, and also the tender twigs and leaves of the Peepul and other trees, which they chew, swallow the juice thereof, and reject the indigestible part. They are easily tamed, and when first taken show no disposition to bite unless provoked to anger, and even then manifest a reluctance to defend themselves, preferring to retreat into some corner rather than to attack their enemy ; they walk erect, and, when placed upon a floor or in an open field, balance themselves very prettily, by raising their hands over their head and slightly bending the arm at the wrist and elbow, and then run tolerably fast, rocking from side to side; and if urged to greater speed, they let fall their hands to the ground, and assist themselves forward, rather jumping than running; still keeping the body however nearly erect-if they succeed in making their way to a grove of trees, they then swing with such astonishing rapidity from branch to branch, and from tree to tree, that they are soon lost in the jungle or forest.

"The individual in question became so tame and manageable in less than a month, that he would take hold of my hand and walk with me, helping himself along at the same time with the other hand applied to the ground as described above. He would come at my call and seat himself in a chair by my side at the breakfast table, and help himself to an egg, or the wing of a chicken from my plate, without endangering any of my table furniture-he would partake of coffee, chocolate, milk, VoL. IV.-P 
tea, \&c., and although his usual mode of taking liquids was by dipping his knuckles into the cup and licking his fingers, still, when apparently more thirsty, he would take up the vessel from which I fed him with both hands, and drink like a man from a spring; his principal food consisted of boiled rice, boiled bread and milk with sugar, plantains, bananas, oranges, \&c., all of which he ate, but seemed best pleased with bananas; he was fond of insects, would search in the crevices of my house for spiders, and if a fly chanced to come in his reach he would dexterously catch him in one hand, generally using his right hand. Like many of the different religious castes of this country, he seemed to entertain an antipathy to an indiscriminate use of animal food and would not eat of either the flesh of the cow or hog, would sometimes taste a little piece of beef, but never eat of it; I have seen him take fried fish, which he seemed to relish better than almost any other description of animal food with the exception of chicken, and even this he would eat but very sparingly of, preferring his common diet, bread and milk, and milk with sugar, fruit, \&c. In temper he was remarkably pacific, and seemed, as I thought, often glad to have an opportunity of testifying his affection and attachment for me. When I visited him in the morning, he would commence a loud and shrill Whoo-whoowhoo-whoo, which he would keep up often from five to ten minutes, with an occasional intermission for the purpose of taking a full respiration; until finally, apparently quite exhausted, he would lie down and allow me to comb his head, and brush the long hair on his arms, and seemed delighted with the tickling sensation produced by the brush on his belly and legs; he would turn from side to side, first hold out one arm and then the other, and when I attempted to go away he would catch hold of my arm or coat tail, and pull me back again to renew my little attentions to him, daily bestowed; if I called to him from a distance and he could recognize my voice, he would at once set up his usual cry, which he sometimes gradually brought down to a kind of moan, but generally resumed his louder tone when I approached him. This animal was a male, but showed no particular marks of the sex, and by a casual glance might readily, if not examined more closely, have passed for a female. I have no idea of his age, but judging from the size and length of his canine teeth, suppose him to have been advanced in life. 
"The other large 'Hoolock,' of which you have the cranium, was also a male and full grown; he was likewise obtained from the GarrowHills in Assam, presented to me by my friend Captain A. Davidson of Goalpara. He came into my possession in the month of April, and died at sea in July, just before getting up with the Cape of Good Hope, of a catarrhal affection : his death probably might have been hastened from the want of proper food, such as is not procurable on long voyages. This animal was similar in habit and general characters to the one already described, and may have been eight or ten years of age or perhaps older, as I am informed by the natives of Assam they live to the age of twenty-five or thirty years.

"The young specimen was also alive in my possession-this is a female, and was brought to me by a Garrow Indian at the same time the first was received, but died on the way from Goalpara to Calcutta of a pulmonary disease following catarrh. This poor little creature when first taken sick suffered great pain and oppression at the chest, for which I prescribed a cathartic of castor oil and calomel, and a warm bath, which seemed to afford it some temporary relief, but she died after ten days illness. The animal appeared delighted with the bath, and when I removed her from the vessel she would run back again to the water, and lie down again until again removed; she was, like the others I had in my possession, gentle and pacific in disposition, very timid and shy of strangers, but in less than a week from the time she was taken, would, if put down in an open place, quickly run to me, jump in my arms and hug me round the neck. I supposed her to have been from nine months to a year old. I fed her on boiled milk, goat's milk diluted with water and sweetened with sugar candy; she also would sometimes partake of a little bread and milk with the older one; she soon learned to suck the milk from a small bottle, through a quill covered with a piece of rag.

\section{"M. BURROUGH."}

"Nov. 19th, 1830." 


\section{$2 \mathrm{BHL}$ Biodiversity Heritage Library}

Harlan, Richard. 1834. "Description of a Species of Orang, from the north-eastern province of British East India, lately the kingdom of Assam." Transactions of the American Philosophical Society 4, 52-59.

View This Item Online: https://www.biodiversitylibrary.org/item/79816

Permalink: https://www.biodiversitylibrary.org/partpdf/92660

\section{Holding Institution}

University of Pittsburgh Library System (archive.org)

\section{Sponsored by}

Lyrasis Members and Sloan Foundation

\section{Copyright \& Reuse}

Copyright Status: Not provided. Contact Holding Institution to verify copyright status.

This document was created from content at the Biodiversity Heritage Library, the world's largest open access digital library for biodiversity literature and archives. Visit BHL at https://www.biodiversitylibrary.org. 